\title{
PENGARUH PENERAPAN SISTEM ABSENSI FINGER PRINT TERHADAP DISIPLIN PEGAWAI PADA MARKAS KOMANDO DIREKTORAT PENGAMANAN BADAN PENGUSAHAAN BATAM
}

\author{
Risfa Fadila $^{1}$ ), Maryani Septiana ${ }^{2}$ ) \\ 1) Prodi Administrasi Bisnis Terapan, Politeknik Negeri Batam, Batam, Indonesia, \\ Email : risfafadilaa@gmail.com \\ 2) Prodi Administrasi Bisnis Terapan, Politeknik Negeri Batam, Batam, Indonesia, \\ Email: maryaniseptiana@polibatam.ac.id
}

\begin{abstract}
This study aims to examine and analyze the effect of the application of fingerprint attendance on employee discipline in Markas Komando Direktorat Pengamanan Badan Pengusahaan Batam. Data collected through distributing questionnaires to 55 respondents. A sampling technique uses a saturation sampling. The data analysis method used is quantitative analysis using validity and reliability testing, classic assumption test, $F$ test, $t$ test, coefficient of determination and multiple linear regression analysis. The results of data analysis show that 1) the practical dimensions of fingerprint attendance have a positive but not significant effect on employee discipline, 2) the accurate dimension of fingerprint attendance has a positive but not significant effect on employee discipline, 3) high securities fingerprint attendance has a positive and significant effect on employee discipline, 4) the dimensions of fingerprint attendance hardware have a positive but not significant effect on employee discipline, 5) practical, accurate, high security, and fingerprint attendance hardware simultaneously have a positive and significant effect on employee discipline.
\end{abstract}

Keywords: discipline, fingerprint, attendance system.

\begin{abstract}
Abstrak
Penelitian ini bertujuan untuk menguji dan menganalisis pengaruh penerapan absensi fingerprint terhadap disiplin pegawai di Markas Komando Direktorat Pengamanan Badan Pengusahaan Batam. Pengumpulan data dilakukan melalui penyebaran kuesioner kepada 55 responden. Metode pengambilan sampel dengan menggunakan sampling jenuh. Metode analisis data yang digunakan adalah analisis kuantitatif dengan menggunakan uji validitas dan uji reliabilitas, uji asumsi klasik, uji F, uji t, koefisien determinasi dan analisis regresi linier berganda. Hasil analisis data menunjukkan bahwa 1) dimensi praktis absensi fingerprint berpengaruh positif tetapi tidak signifikan terhadap disiplin pegawai, 2) dimensi akurat absensi fingerprint berpengaruh positif tetapi tidak signifikan terhadap disiplin pegawai, 3) dimensi sekuritas tinggi absensi fingerprint berpengaruh positif dan signifikan terhadap disiplin pegawai, 4) dimensi perangkat keras absensi fingerprint berpengaruh positif tetapi tidak signifikan terhadap disiplin pegawai, 5) dimensi praktis, akurat, sekuritas tinggi, dan perangkat keras absensi fingerprint secara simultan berpengaruh positif dan signifikan terhadap disiplin pegawai.
\end{abstract}

Kata Kunci: Disiplin, Fingerprint, Sistem Absensi 


\section{LATAR BELAKANG}

Di dalam sebuah perusahaan salah satu faktor penting yang dapat menciptakan sebuah perusahaan yang maju ialah sumber daya manusia. Sumber daya manusia dapat memiliki definisi, seseorang yang bekerja atau memiliki kemampuan untuk dikembangkan dan merupakan aset penting yang bekerja demi mencapai tujuan dari suatu organisasi. Namun didalam pelaksanaanya terkadang muncul permasalahan yang berhubungan dengan sumber daya manusia didalam sebuah perusahaan tersebut, sehingga akan berpengaruh terhadap kinerja dari pegawai. Maka dari itu tindakan pengawasan perlu dilakukan terhadap pegawai agar tujuan suatu perusahaan dapat tercapai. Dalam melakukan pengawasan salah satu cara yang dapat dilakukan sebuah perusahaan adalah dengan memonitoring daftar absensi kehadiran pegawai. Saat ini banyak perusahaan yang telah menggunakan sistem yang lebih modern dalam pencatatan absensi guna tercapainya tujuan dalam meningkatkan disiplin kerja pegawai, yaitu sudah mulai menggunakan alat fingerprint. Menurut Suryadi dalam Muslikhun (2016) mengemukakan bahwa mesin absensi sidik jari (fingerprint) adalah mesin absensi yang menggunakan sidik jari, dimana sidik jari tiap orang memiliki bentuk yang berbedabeda oleh karena itu mesin tersebut otomatis tidak dapat dimanipulasi.

Hal ini dapat melihat tindakan disiplin pegawai karena kedisiplinan pegawai merupakan salah satu ukuran kesuksesan dari sebuah perusahaan. Disamping itu disiplin memberikan manfaat yang mendidik bagi para pegawai sehingga menghasilkan kinerja yang baik. Pada dasarnya disiplin dapat mengambarkan besarnya tanggung jawab seseorang terhadap tugas yang diberikan dan upaya pengendalian dan pengawasan kerja perlu dilakukan secara terus-menerus dan konsisten.

Penerapan sistem absensi fingerprint di Markas Komando Direktorat Keamanan Pengamanan Badan Pengusahaan Batam diterapkan sejak tahun 2015. Dalam penggunaan absensi fingerprint masalah yang ditemukan di Markas Komando Direktorat Pengamanan Badan Pengusahaan Batam adalah verifikasi sidik jari yang dilakukan oleh pegawai terkadang tidak terekam oleh mesin fingerprint sehingga pegawai dianggap mangkir bekerja pada hari tersebut. Tindakan evaluasi yang dilakukan dengan penggunaan absensi fingerprint ini adalah setiap akhir bulan para pegawai akan menerima hasil rekap absensi pada bulan itu, dimana dalam rekap tersebut apabila pegawai tidak masuk atau terlambat dalam bekerja, maka pada kolom rekap absen tersebut akan berwarna merah dan pegawai tersebut akan mendapatkan sanksi berupa pemotongan gaji atas pelanggaran jam kerja tersebut.

\section{Rumusan Masalah}

Berdasarkan latar belakang yang telah dipaparkan sebelumnya, maka rumusan masalah dalam penelitian ini adalah sebagai berikut:

1. Sejauh mana pengaruh dimensi praktis $\left(\mathrm{X}_{1}\right)$ absensi fingerprint terhadap disiplin pegawai di Markas Komando Direktorat

Pengamanan BadanPengusahaan

Batam.

2. Sejauh mana pengaruh dimensi akurat $\left(\mathrm{X}_{2}\right)$ absensi fingerprint terhadap disiplin pegawai di Markas Komando Direktorat

Pengamanan BadanPengusahaan Batam.

3. Sejauh mana pengaruh dimensi sekuritas tinggi $\left(\mathrm{X}_{3}\right)$ absensi fingerprint terhadap disiplin pegawai di Markas Komando Direktorat Pengamanan Badan Pengusahaan Batam.

4. Sejauh mana pengaruh dimensi perangkat keras $\left(\mathrm{X}_{4}\right)$ absensi fingerprint terhadap disiplin pegawai di Markas Komando Direktorat Pengamanan Badan Pengusahaan Batam. 
Risfa Fadila \& Maryani S, Pengaruh Penerapan Sistem Absensi...

5. Sejauh mana pengaruh praktis, dimensi, sekuritas tinggi, dan perangkat keras absensi fingerprint terhadap disiplin pegawai di Markas Komando Direktorat Pengamanan Badan Pengusahaan Batam

\section{Tujuan Penelitian}

Berdasarkan uraian yang telah dipaparkan maka penelitian ini mempunyai tujuan yang ingin dicapai yaitu:

1. Untuk mengetahui sejauh mana pengaruh antara dimensi praktis mesin absensi fingerprint terhadap disiplin pegawai di Markas Komando Direktorat Pengamanan Badan Pengusahaan Batam.

2. Untuk mengetahui sejauh mana pengaruh antara dimensi akurat mesin absensi fingerprint terhadap disiplin pegawai di Markas Komando Direktorat

Pengamanan BadanPengusahaan

Batam.

3. Untuk mengetahui sejauh mana pengaruh antara dimensi sekuritas tinggi mesin absensi fingerprint terhadap disiplin pegawai di Markas Komando Direktorat Pengamanan Badan Pengusahaan Batam.

4. Untuk mengetahui sejauh mana pengaruh antara dimensi perangkat keras absensi fingerprint terhadap disiplin pegawai di Markas Komando Direktorat Pengamanan Badan Pengusahaan Batam

5. Untuk mengetahui sejauh mana pengaruh praktis, dimensi, sekuritas tinggi, dan perangkat keras absensi fingerprint terhadap disiplin pegawai di Markas Komando Direktorat Pengamanan Badan Pengusahaan Batam

\section{Manfaat Penelitian}

Manfaat praktis yang diharapkan dari peneltian ini adalah dapat menjadi saran dan masukan untuk mengambil langkah yang tepat dalam rangka meningkatkan disiplin pegawai di Markas Komando Direktorat Pengamanan Badan
Pengusahaan Batam. Dan manfaat teoritis Bagi pembaca, dapat menambah wawasan pengetahuan khususnya mengenai penerapan absensi fingerprint terhadap disiplin pegawai. Bagi penulis, dapat dijadikan bahan perbandingan antara teori dengan kenyataan yang terjadi di sebuah perusahaan sehingga dapat menambah pengetahuan.

\section{KAJIAN PUSTAKA}

Absensi Fingerprint

Absensi adalah suatu kegiatan atau rutinitas yang dilakukan oleh pegawai untuk membuktikan dirinya hadir atau tidak hadir dalam bekerja disuatu instansi (Erna, 2012). Absensi ini berkaitan dengan penerapan disiplin yang ditentukan oleh masing-masing instansi. Salah satu penerapan teknologi guna mencapai tujuan dalam meningkatkan disiplin pegawai adalah dengan menerapkan absensi fingerprint pada sebuah instansi Menurut Moch Tofik (2010) memberikan penjelasan bahwa fingerprint adalah teknologi yang menunjang untuk keperluan absensi, yang di dalamnya mencakup pemasukan, penyimpanan data jam masuk dan jam pulang, memproses data tersebut menjadi sebuah laporan yang nantinya dapat dipergunakan untuk pengambilan kebijakan-kebijakan yang dilakukan oleh pimpinan.

Menurut Moch Tofik (2010), ada tiga dimensi absensi sidik jari (fingerprint) yaitu:

1. Praktis, pegawai dapat membuktikan kehadiran hanya dengan meletakkan salah satu jari pada mesin absensi fingerprint.

2. Akurat, mesin absensi fingerprint memiliki tingkat akurasi yang tinggi dalam merekam data absensi pegawai.

3. Sekuritas Tinggi, sistem absensi fingerprint memiliki resiko paling kecil untuk dilakukan manipulasi.

Mesin absensi fingerprint merupakan sistem informasi manajemen yang mengandung elemen-elemen fisik seperti yang diungkapkan oleh Davis (2005): 
a. Perangkat keras komputer, terdiri atas komputer (merupakan pusat pengelolaan, unit masukan/keluar, unit penyimpanan file, dan peralatan penyimpanan data).

b. Data Base, (dimana data-data yang ada tersimpan terdapat di dalam media penyimpanan komputer).

c. Prosedur, komponen-komponen prosedur yang dapat dilihat dengan nyata dan dipegang fisiknya. Prosedur ini dapat berbentuk instruksi dan buku bantuan operasional.

d. Personalia pengoperasian, seperti: operator komputer, analisa sistem pembuatan program, personalia penyimpanan data dan sistem informasi.

\section{Disiplin Pegawai}

Menurut Zainul (2012) disiplin merupakan keadaan yang menyebabkan atau memberikan dorongan kepada karyawan untuk berbuat dan melakukan segala kegiatan sesuai dengan norma atau aturan yang telah ditetapkan. Disiplin menunjukkan suatu kondisi atau sikap hormat yang ada ada diri pegawai terhadap peraturan dan ketetapan perusahaan. Dengan demikian apabila peraturan atau ketetapan yang ada di dalam perusahaan tersebut dilanggar, maka pegawai mempunyai disiplin kerja yang kurang baik. Sebaliknya apabila pegawai taat pada ketetapan perusahaan, menunjukkan kondisi disiplin pegawai yang baik.

\section{Kerangka Pemikiran}

Kerangka Pemikiran adalah sebuah pemahaman yang melandasi pemahamanpemahaman lainnya. Kerangka pemikiran digunakan untuk memperjelas gambaran isi penelitian. Kerangka dari penelitian ini adalah sebagai berikut:

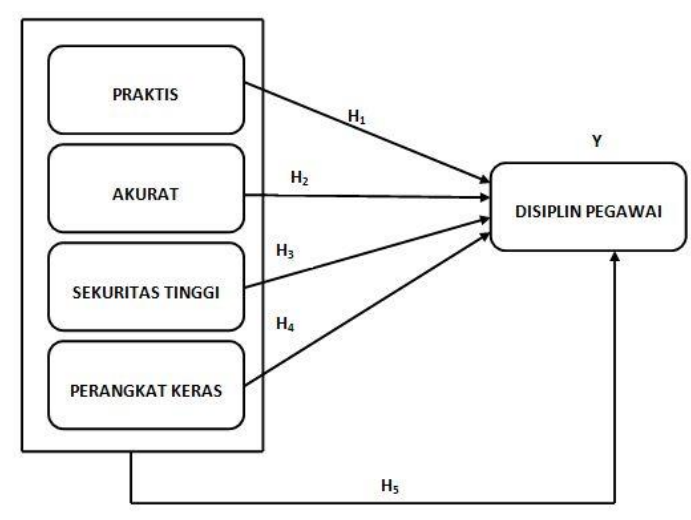

\section{OBJEK DAN RUANG LINGKUP PENELITIAN}

Objek pada penelitian ini adalah pegawai di Markas Komando Direktorat Pengamanan Badan Pengusahaan Batam.

\section{Hipotesis}

Dalam penelitian ini, terdapat lima hipotesis diantaranya:

$\mathrm{H}_{1} \quad$ Dimensi praktis pada pada mesin absensi fingerprint mempunyai pengaruh yang positif dan signifikan terhadap disiplin pegawai

$\mathrm{H}_{2}$ Dimensi akurat pada pada mesin absensi fingerprint mempunyai pengaruh yang positif dan signifikan terhadap disiplin pegawai

$\mathrm{H}_{3} \quad$ Dimensi sekuritas tinggi pada pada mesin absensi fingerprint mempunyai pengaruh yang positif dan signifikan terhadap disiplin pegawai.

$\mathrm{H}_{4} \quad$ Dimensi perangkat keras pada pada mesin absensi fingerprint mempunyai pengaruh yang positif dan signifikan terhadap disiplin pegawai.

$\mathrm{H}_{5}$ Dimensi praktis, akurat, sekuritas tinggi, dan perangkat keras secara simultan berpengaruh positif dan signifikan terhadap disiplin pegawai.

\section{Populasi dan Sampel}

Menurut Sugiyono (2018) populasi adalah wilayah generalisasi yang terdiri atas: obyek/subyek yang mempunyai kualitas dan karakteristik tertentu yang ditetapkan oleh peneliti untuk dipelajari dan kemudian ditarik kesimpulannya. 
Risfa Fadila \& Maryani S, Pengaruh Penerapan Sistem Absensi...

Populasi pada penelitian ini adalah pegawai di Markas Komando Direktorat Pengamanan Badan Pengusahaan Batam.

Teknik penentuan sampel yang digunakan dalam penelitian ini adalah sampling jenuh, yaitu teknik penentuan sampel bila semua anggota populasi digunakan sebagai sampel (Sugiyono, 2018). Dalam penelitian ini, sampel adalah seluruh populasi di Markas Komandan Direktorat Pengamana Badan Pengusahaan Batam yang dijadikan sampling yaitu sebanyak 55 pegawai

\section{Jenis dan Sumber Data}

Jenis dan sumber data yang digunakan dalam penelitian ini adalah sebagai berikut:

a. Data primer adalah data yang diperoleh secara langsung dengan menyebarkan kuesioner kepada pegawai di Markas Komando Direktorat Pengamanan Badan Pengusahaan Batam.

b. Data sekunder adalah data yang sudah ada dan tersusun secara sistematis serta merupakan hasil penelitian atau rangkuman dari dokumen-dokumen yang berhubungan dengan masalah yang diteliti seperti buku, dan jurnal.

\section{Teknik Pengumpulan Data}

Teknik pengumpulan data yang digunakan dalam penelitian ini adalah sebagai berikut:

1. Kuisioner, adalah seperangkat pertanyaan yang disusun untuk diajukan kepada responden. Kuisionere ini dimaksudkan untuk memperoleh informasi tertulis dari responden.

2. Studi dokumen, mengumpulkan informasi dengan memperlajari sumber data tertulis yang dilakukan untuk memperoleh data sekunder yang ada kaitannya dengan penelitian yang dilakukan, misalnya struktur organisasi, dan jumlah pegawai.

\section{Metode Analisis Data}

Metode analisis data adalah proses pengumpulan data secara sistematis untuk mempermudah peneliti dalam memperoleh kesimpulan.

\section{Analisis Statistik Deskriptif}

Statistik deskriptif adalah statistik yang digunakan untuk menganalisis data dengan cara mendeskripsikan atau menggambarkan data yang telah terkumpul sebagaimana adanya tanpa bermaksud membuat kesimpulan yang berlaku untuk umum dan generalisasi (Sugiyono,2017).

\section{Validitas dan Reliabilitas}

Validitas menurut Sugiyono (2018), derajat ketetapan antara data yang terjadi pada objek penelitian dengan data yang dapat dilaporkan oleh penelitian. Dengan demikian data yang valid adalah data "yang tidak berbeda" antara data yang dilaporkan oleh peneliti dengan data yang sesungguhnya terjadi pada objek penelitian. Hasil $r$ hitung kita bandingkan dengan $r$ tabel dengan sig 5\%. Jika $r$ tabel $<\mathrm{r}$ hitung maka valid.

\begin{tabular}{|c|c|c|c|c|}
\hline \multirow[t]{2}{*}{ Wariabel } & \multicolumn{4}{|c|}{ Validitas } \\
\hline & Item & r hitung & $\mathrm{r}$ tabel & Kesimpulan \\
\hline \multirow{5}{*}{$\begin{array}{l}\text { Dimensi } \\
\text { Praktis }\left(\mathrm{X}_{1}\right)\end{array}$} & X1.P1 & 0,695 & 0,2656 & Valid \\
\hline & $\mathrm{X} 1 . \mathrm{P} 2$ & 0,618 & 0,2656 & Valid \\
\hline & X1.P3 & 0,753 & 0,2656 & Valid \\
\hline & X1.P4 & 0,768 & 0,2656 & Valid \\
\hline & X1.P5 & 0,670 & 0,2656 & Valid \\
\hline \multirow{2}{*}{$\begin{array}{l}\text { Dimensi } \\
\text { Akurat }\left(\mathrm{X}_{2}\right)\end{array}$} & $\mathrm{X} 2 . \mathrm{P} 1$ & 0,897 & 0,2656 & Valid \\
\hline & $\mathrm{X} 2 . \mathrm{P} 2$ & 0,897 & 0,2656 & Valid \\
\hline \multirow{3}{*}{$\begin{array}{l}\text { Dimensi } \\
\text { Sekuritas } \\
\text { Tinggi }\left(\mathrm{X}_{3}\right)\end{array}$} & X3.P1 & 0,817 & 0,2656 & Valid \\
\hline & $\mathrm{X} 3 . \mathrm{P} 2$ & 0,840 & 0,2656 & Valid \\
\hline & X3.P3 & 0,783 & 0,2656 & Valid \\
\hline \multirow{4}{*}{$\begin{array}{l}\text { Dimensi } \\
\text { Perangkat } \\
\text { Keras (X. }\end{array}$} & X4.P1 & 0,729 & 0,2656 & Valid \\
\hline & $\mathrm{X} 4 . \mathrm{P} 2$ & 0,849 & 0,2656 & Valid \\
\hline & X4.P3 & 0,470 & 0,2656 & Valid \\
\hline & X4.P4 & 0,762 & 0,2656 & Valid \\
\hline \multirow{11}{*}{$\begin{array}{l}\text { Disiplin } \\
\text { Pegawai } \\
\text { (Y) }\end{array}$} & Y1.P1 & 0,623 & 0,2656 & Valid \\
\hline & Y2.P2 & 0,538 & 0,2656 & Valid \\
\hline & Y3.P3 & 0,794 & 0,2656 & Valid \\
\hline & Y4.P4 & 0,732 & 0,2656 & Valid \\
\hline & Y5.P5 & 0,670 & 0,2656 & Valid \\
\hline & Y6.P6 & 0,786 & 0,2656 & Valid \\
\hline & Y7.P7 & 0,662 & 0,2656 & Valid \\
\hline & Y8.P8 & 0,704 & 0,2656 & Valid \\
\hline & Y9.P9 & 0,680 & 0,2656 & Valid \\
\hline & Y10.P10 & 0,618 & 0,2656 & Valid \\
\hline & Y11.P11 & 0,617 & 0,2656 & Valid \\
\hline
\end{tabular}

Berdasarkan tabel dapat diketahui bahwa seluruh butir pernyataan tentang praktis, akurat, sekuritas tinggi, perangkat keras, dan disiplin pegawai mempunyai nilai $r_{\text {hitung }}>r_{\text {tabel }} 0,2656$, sehingga seluruh butir pernyataan dikatakan valid.

Uji reliabilitas menurut Sugiyono (2018), dilakukan untuk mengetahui seberapa jauh hasil pengukuran tetap konsisten apabila dilakukan pengukuran dua kali atau lebih terhadap gejala yang sama dengan menggunakan alat pengukur yang sama. 


\begin{tabular}{|l|c|c|c|}
\hline \multirow{2}{*}{ Yariabel } & \multicolumn{3}{|c|}{ Reliabilitas } \\
\cline { 2 - 4 } & $\begin{array}{c}\text { Koefisien } \\
\text { Cronchach's } \\
\text { Alpha (a) }\end{array}$ & $\begin{array}{c}\text { Cut Off Alpha } \\
\text { Cronbach }\end{array}$ & Kesimpulan \\
\hline Praktis $\left(\mathrm{X}_{1}\right)$ & 0,742 & 0,60 & Reliabel \\
\hline Akurat $\left(\mathrm{X}_{2}\right)$ & 0,758 & 0,60 & Reliabel \\
\hline $\begin{array}{l}\text { Sekuritas Tinggi } \\
\left(\mathrm{X}_{3}\right)\end{array}$ & 0,743 & 0,60 & Reliabel \\
\hline $\begin{array}{l}\text { Perangkat Keras } \\
\left(\mathrm{X}_{4}\right)\end{array}$ & 0,669 & 0,60 & Reliabel \\
\hline $\begin{array}{l}\text { Disiplin Pegawai } \\
(\mathrm{Y})\end{array}$ & 0,876 & 0,60 & Reliabel \\
\hline
\end{tabular}

Hasil uji reliabilitas tersebut menunjukkan bahwa semua variabel mempunyai koefisien Alpha diatas 0,60 sehingga dapat dikatakan konsep pengukur masing-masing variabel dari kuesioner adalah reliabel sehingga untuk selanjutnya item-item pada masing-masing konsep variabel tersebut layak digunakan sebagai alat ukur.

\section{Uji Asumsi Klasik}

\section{Uji Normalitas}

Dalam penelitian ini untuk menguji normalitas data penulis menggunakan teknik one sample Kolmogorov-Smirnov Test

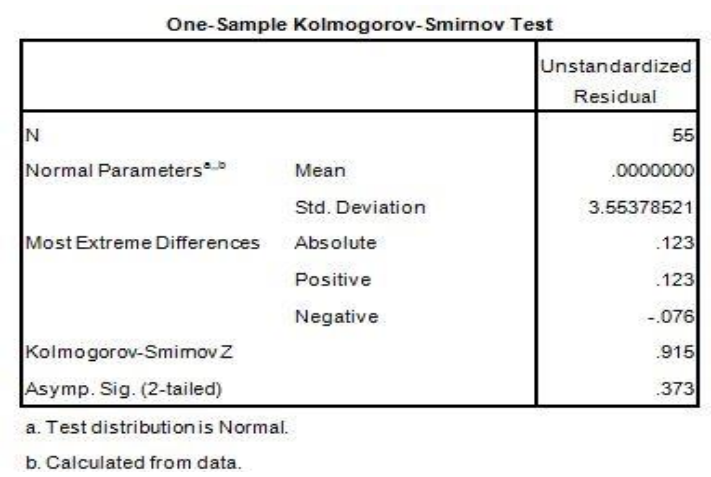

Dari tabel dapat dilihat bahwa hasil

Uji Normalitas menyatakan nilai Asymp.Sig. (2-tailed) sebesar 0,373 > 0,05. Berdasarkan hasil tersebut dapat dinyatakan data yang digunakan dalam penelitian ini telah berdistribusi normal.

\section{Uji Multikolinearitas}

Multikoliniaritas dapat dilihat dari nilai tolerance dan nilai variance inflation factor (VIF). Jika nilai Tolerance $>0,1$ atau sama dengan nilai $\mathrm{VIF}<10$, maka dapat disimpulkan bahwa tidak ada multikoliniaritas antar variabel independen dalam modek regresi pada penelitian ini.

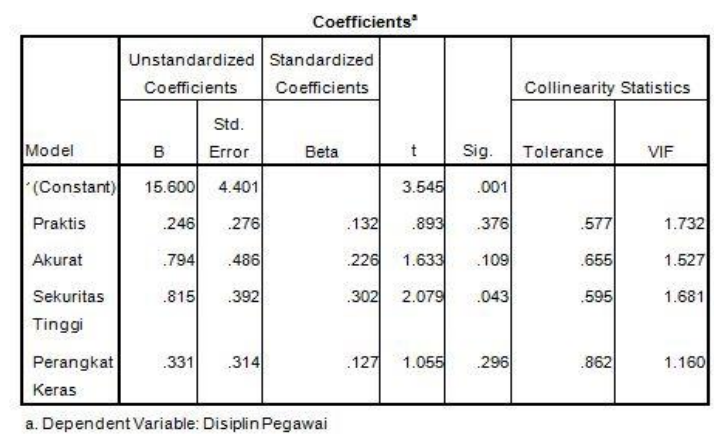

Dari tabel dapat dilihat bahwa dimensi praktis $\left(\mathrm{X}_{1}\right)$ nilai tolerance $0,577>$ 0,1 dan nilai VIF $1,732<10$, dimensi akurat $\left(\mathrm{X}_{2}\right)$ nilai tolerance $0,655>0,1$ dan nilai VIF $1,527<10$, dimensi sekuritas tinggi $\left(\mathrm{X}_{3}\right)$ nilai tolerance $0,595>0,1$ dan nilai VIF $1,681<10$, dimensi perangkat keras $\left(\mathrm{X}_{4}\right)$ nilai tolerance $0,682>0,1$ dan nilai VIF $1,160<10$. Merujuk hasil perhitungan nilai Tolerance dan VIF dapat disimpulkan bahwa tidak ada gejala multikolinearitas antar variabel independen dalam model regresi.

\section{Uji Heteroskedastisitas}

Cara untuk mengetahui terjadi heteroskedastisitas atau tidak yaitu dengan melihak grafik Plot antara nilai prediksi variabel dependen yaitu ZPRED dengan residualnya SREID. Tidak terjadi heteroskedastisitas yaitu apabila tidak ada pola yang jelas serta titik-tik menyebar di atas dan di bawah angka 0 pada sumbu Y.

scatterplot

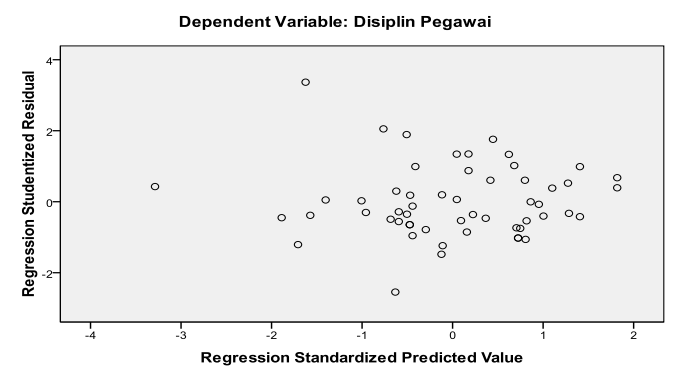

Berdasarkan gambar di atas terlihat bahwa tidak ada pola yang jelas serta titiktitik tersebut mnyebar di atas dan di bawah angka 0 pada sumbu Y. Hal ini menunjukkan bahwa data dalam penelitian ini tidak terjadi heteroskedastisitas. 
Risfa Fadila \& Maryani S, Pengaruh Penerapan Sistem Absensi...

Analisis Regresi Linear Berganda

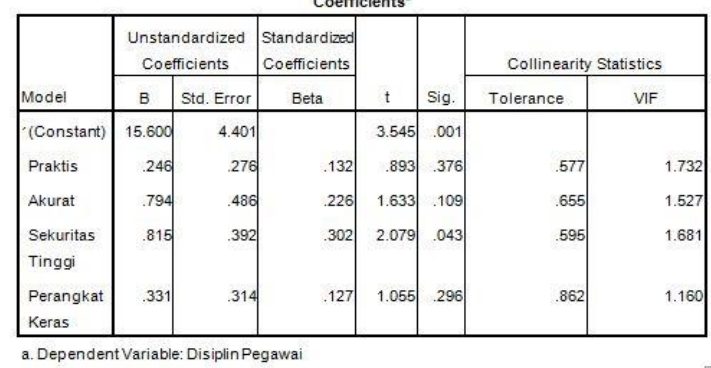

Berdasarkan pada tabel maka didapatkan persamaan regresi linier berganda sebagai berikut:

$Y=0,246 X_{1}+0,794 X_{2}+0,815 X_{3}+0,331$ $\mathbf{X}_{4}$

Persamaan di atas dapat dijelaskan sebagai berikut:

1. Nilai 0,246 pada variabel praktis $\left(X_{1}\right)$ adalah bernilai positif sehingga dapat dikatakan bahwa semakin tinggi tingkat praktis sistem absensi fingerprint, maka akan semakin tinggi pula tingkat disiplin pegawai.

2. Nilai 0,794 pada variabel akurat $\left(X_{2}\right)$ adalah bernilai positif sehingga dapat dikatakan bahwa semakin tinggi tingkat akurat sistem absensi fingerprint, maka akan semakin tinggi pula tingkat disiplin pegawai.

3. Nilai 0,815 pada variabel akurat $\left(\mathrm{X}_{3}\right)$ adalah bernilai positif sehingga dapat dikatakan bahwa semakin tinggi tingkat sekuritas tinggi sistem absensi fingerprint, maka akan semakin tinggi pula tingkat disiplin pegawai.

4. Nilai 0,331 pada variabel akurat $\left(\mathrm{X}_{4}\right)$ adalah bernilai positif sehingga dapat dikatakan bahwa semakin tinggi tingkat kualitas perangkat keras absensi fingerprint, maka akan semakin tinggi pula tingkat disiplin pegawai.

\section{Uji F}

Uji F dilakukan untuk melihat ada tidaknya pengaruh variabel-variabel bebas (praktis, akurat, sekuritas tinggi, dan perangkat keras) terhadap variabel terikat (disiplin pegawai) secara bersama-sama.

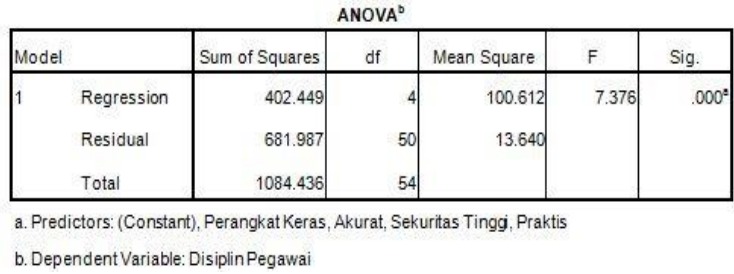

Dari hasil uji $\mathrm{F}$ pada penelitian ini didapatkan angka signifikansi $\mathrm{F}$ sebesar 0,000 . Dengan signifikansi $95 \%(\alpha=0,05)$. Angka signifikansi F $0,000<0,05$. Atas dasar perbandingan tersebut, maka $\mathrm{H}_{0}$ ditolak atau berarti variabel praktis, akurat, sekuritas tinggi, dan perangkat keras mempunyai pengaruh yang signifikan secara bersama-sama terhadap variabel disiplin pegawai.

\section{Uji t}

Uji t dilakukan untuk melihat ada tidaknya pengaruh variabel-variabel bebas (praktis, akurat, sekuritas tinggi, perangkat keras) terhadap variabel terikat (disiplin pegawai) secara parsial.

\begin{tabular}{|c|c|c|c|c|c|}
\hline & & Coefficie & ents ${ }^{2}$ & \multirow[b]{3}{*}{$t$} & \multirow[b]{3}{*}{ Sig. } \\
\hline \multirow[b]{2}{*}{ Model } & \multicolumn{2}{|c|}{$\begin{array}{l}\text { Unstandardized } \\
\text { Coefficients }\end{array}$} & \multirow{2}{*}{\begin{tabular}{|c|}
$\begin{array}{c}\text { Standardized } \\
\text { Coefficients }\end{array}$ \\
Beta \\
\end{tabular}} & & \\
\hline & B & Std. Error & & & \\
\hline 1 (Constant) & 15.600 & 4.401 & & 3.545 & .001 \\
\hline Praktis & .246 & .276 & .132 & .893 & .376 \\
\hline Akurat & .794 & .486 & .226 & 1.633 & .109 \\
\hline Sekuritas Tinggi & .815 & 392 & .302 & 2.079 & .043 \\
\hline Perangkat Keras & .331 & .314 & .127 & 1.055 & .296 \\
\hline
\end{tabular}

1. Pengujian Hipotesis 1, dimensi praktis absensi fingerprint tidak berpengaruh terhadap disiplin pegawai.

Berdasarkan tabel dapat diketahui variabel $\mathrm{X}_{1}$ dimensi praktis memiliki nilai signifikan sebesar $0,376 .>\alpha=$ 0,05, maka dapat dikatakan variabel praktis absensi fingerprint tidak berpengaruh terhadap disiplin pegawai. Sehingga hipotesis pertama menyatakan bahwa dimensi praktis absensi fingerprint tidak berpengaruh signifikan terhadap disiplin pegawai.

2. Pengujian Hipotesis 2, dimensi praktis akurat absensi fingerprint tidak berpengaruh terhadap disiplin pegawai. Berdasarkan tabel dapat diketahui variabel $\mathrm{X}_{2}$ dimensi akurat memiliki nilai signifikan sebesar 0,109. $>\alpha=$ 
0,05, maka dapat dikatakan variabel akurat absensi fingerprint tidak berpengaruh terhadap disiplin pegawai sehingga hipotesis kedua menyatakan bahwa dimensi akurat absensi fingerprint tidak berpengaruh signifikan terhadap disiplin pegawai.

3. Pengujian Hipotesis 3, dimensi sekuritas tinggi absensi fingerprint berpengaruh terhadap disiplin pegawai. Berdasarkan tabel dapat diketahui variabel $\mathrm{X}_{3}$ dimensi sekuritas tinggi memiliki nilai signifikan sebesar 0,043 $<\alpha=0,05$, maka dapat dikatakan variabel sekuritas tinggi absensi fingerprint berpengaruh terhadap disiplin pegawai sehingga hipotesis ketiga menyatakan bahwa dimensi sekuritas tinggi absensi fingerprint berpengaruh signifikan terhadap disiplin pegawai.

4. Pengujian Hipotesis 4, dimensi perangakt keras absensi fingerprint tidak berpengaruh terhadap disiplin pegawai.

Berdasarkan tabel dapat diketahui variabel $\mathrm{X}_{4}$ dimensi perangkat keras memiliki nilai signifikan sebesar 0,296. $>$ dari dari $\alpha=0,05$, maka dapat dikatakan variabel perangkat keras absensi fingerprint tidak berpengaruh terhadap disiplin pegawai sehingga hipotesis keempat menyatakan bahwa dimensi perangkat keras absensi fingerprint tidak berpengaruh signifikan terhadap disiplin pegawai.

\section{Koefisien determinasi (R2)}

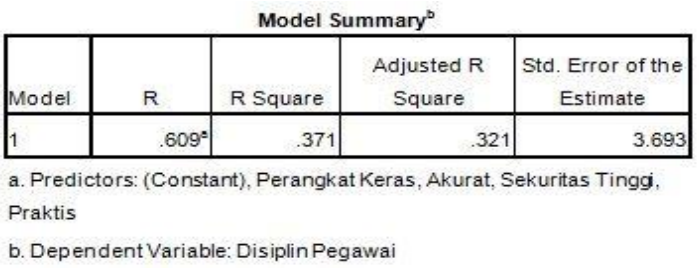

Koefisien determinasi (R2) pada intinya mengukur seberapa jauh kemampuan model dalam menerangkan variabel dependen. Nilai koefisien determinasi (R2) yang kecil berarti kemampuan variabel-variabel independen dalam menjelaskan variabel dependen, terbatas.

Pada tabel dapat dilihat bahwa nilai Adjusted R2 adalah sebesar 0,321. Hal ini dapat diartikan bahwa variabel independen (praktis, akurat, sekuritas tinggi, dan perangkat keras) dapat menjelaskan variabel dependen (disiplin pegawai) sebesar 32,1\%, sedangkan selebihnya diterangkan oleh variabel lain yang tidak diajukan dalam penelitian ini.

\section{Pembahasan \\ Hipotesis 1}

Pernyataan hipotesis pertama bahwa dimensi praktis absensi fingerprint berpengaruh positif dan signifikan terhadap disiplin pegawai tidak terbukti. Hal ini dapat ditunjukkan dengan nilai signifikansi $\mathrm{t}$ sebesar 0,376 yang jauh diatas 0,05 serta nilai koefisien regresi sebesar 0.246. Dapat disimpulkan bahwa dimensi praktis absensi fingerprint berpengaruh positif tetapi tidak signifikan terhadap disiplin pegawai. Hal ini berarti dimensi praktis kemudahan dan kecepatan absensi fingerprint, masih kurang berpengaruh terhadap disiplin pegawai. Hal ini tidak sejalan dengan penelitian sebelumnya oleh Dodi (2017) yang menyatakan bahwa dimensi praktis berpengaruh positif dan signifikan terhadap disiplin pegawai.

\section{Hipotesis 2}

Pernyataan hipotesis kedua bahwa dimensi akurat absnesi fingerprint berpengaruh positif dan signifikan terhadap disiplin pegawai tidak terbukti. Hal ini ditunjukkan dengan nilai signifikansi $\mathrm{t}$ sebesar 0,109 yang jauh diatas 0,05 serta nilai koefisien regresi sebesar 0,794. Dapat disimpulkan bahwa dimensi akurat absensi fingerprint berpengaruh positif tetapi tidak signifikan terhadap disiplin pegawai. Hal ini menunjukkan mesin absensi dapat melakukan proses pembacaan dan verifikasi sidik jari mesin fingerprint ini memiliki ketelitian yang tinggi sehingga dapat menghasilkan data rekam absensi yang akurat, namun hal ini belum mampu 
Risfa Fadila \& Maryani S, Pengaruh Penerapan Sistem Absensi...

untuk meningkatkan disiplin pegawai. Hal ini tidak sejalan dengan penelitian sebelumnya oleh Dodi (2017) yang menyatakan bahwa dimensi akurat berpengaruh positif dan signifikan terhadap disiplin pegawai

\section{Hipotesis 3}

Pernyataan hipotesis ketiga bahwa dimensi sekuritas tinggi absensi fingerprint berpengaruh positif dan signifikan terhadap disiplin pegawai terbukti. Hal ini ditunjukkan dengan nilai signifikansi $\mathrm{t}$ sebesar 0,43 yang lebih kecil dari 0,05 serta nilai koefisien regresi sebesar 0,815 . Dapat disimpulkan bahwa dimensi sekuritas tinggi absensi fingerprint berpengaruh positif dan signifikan terhadap disiplin pegawai. Hal ini dapat dilihat dengan kepercayaan pegawai pada kemampuan sistem absensi fingerprint dalam hal melindungi privasi, keamanan data dari pihak-pihak lain dan memiliki kemungkinan paling kecil untuk dimanipulasi. Hal ini sejalan dengan penelitian sebelumnya oleh Yulianti (2017) yang menyatakan bahwa dimensi sekuritas tinggi berpengaruh positif dan signifikan terhadap disiplin pegawai.

\section{Hipotesis 4}

Pernyataan hipotesis keempat bahwa dimensi perangkat keras absensi fingerprint terhadap disiplin pegawai berperngaruh positif dan signifikan terhadap disiplin pegawai tidak terbukti. Hal ini ditunjukkan dengan nilai signifikansi t sebesar 0,296 yang jauh lebih besar dari 0,05 serta nilai koefisien sebesar 0,331. Dapat disimpulkan bahwa dimensi perangkat keras absensi fingerprint berpengaruh positif tetapi tidak signifikan terhadap disiplin pegawai. Hal ini dapat dilihat jawaban dari beberapa pegawai yang merasa mesin absensi terkadang mengalami kerusakan yang menyebabkan rekam sidik jari para pegawai tidak terekam ke dalam sistem komputer sehingga pegawai merasa mesin absensi fingerprint tidak berjalan sesuai dengan fungsinya. Hal ini tidak sejalan dengan penelitian sebelumnya oleh Erna (2008) yang menyatakan bahwa dimensi perangkat keras berpengaruh positif dan signifikan terhadap disiplin pegawai.

\section{Hipotesis 5}

Pernyataan hipotesis kelima bahwa dimensi praktis, akurat, sekuritas tinggi, dan perangkat keras secara simulatan dan signifikan terhadap disiplin pegawai terbukti. Hal ini ditunjukkan dengan nilai signifikansi f sebesar 0,000 yang lebih kecil dari 0,005. Dapat disimpulkan bahwa dimensi praktis, akurat, sekuritas tinggi, dan perangkat keras secara simultan berpengaruh positif dan signifikan terhadap disiplin pegawai.

\section{Kesimpulan}

1. Variabel praktis berpengaruh positif tetapi tidak signifikan dengan nilai koefisien regresi sebesar 0,246 (24,6 persen). Variabel akurat berpengaruh positif tetapi tidak signifikan dengan nilai koefisien regresi sebesar 0,794 (79,4 persen). Variabel perangkat keras berpengaruh positif tetapi tidak signifikan dengan nilai koefisien regresi sebesar 0,331 (33,1 persen).

2. Sedangkan variabel sekuritas tinggi berpengaruh positif dan signifikan terhadap disiplin pegawai. Hal ini ditunjukkan nilai signifikansi t sebesar 0,43 yang lebih kecil dari 0,05 .

3. Pada pengujian hipotesis dengan menggunakan uji $\mathrm{F}$ (secara bersamasama atau simultan) dapat dijelaskan bahwa keempat variabel yaitu praktis $\left(\mathrm{X}_{1}\right)$, akurat $\left(\mathrm{X}_{2}\right)$, sekuritas tinggi $\left(\mathrm{X}_{3}\right)$, dan perangkat keras $\left(\mathrm{X}_{4}\right)$ secara bersama-sama berpengaruh terhadap disiplin pegawai. Hal ini ditunjukkan dari nilai signifikansi F sebesar 0,000 < 0,05 .

4. Nilai koefisien determinasi $\left(\mathrm{R}^{2}\right)$ yang dihasilkan adalah 0,32. Hal ini berarti sebesar 32 persen variabel disiplin pegawai dapat dijelaskan oleh variabel praktis, akurat, sekuritas tinggi, dan 
perangkat keras secara bersama-sama, sedangkan sisanya sebesar 68 persen dijelaskan oleh variabel lain yang tidak terdapat dalam penelitian ini.

\section{Saran}

Berdasarkan kesimpulan yang telah dilakukan, maka saran yang dapat diberikan pada penelitian ini yaitu:

1. Dengan penerapan absensi fingerprint yang praktis untuk meningkatkan disiplin pegawai di Markas Komando Direktorat Pengamanan Badan Pengusahaan Batam, hendaknya pihak institusi selalu memantau, meninjau, dan memperbaiki pelaksanaan sistem absensi yang sudah ada. Hal ini juga dapat mengurangi sikap pegawai yang tidak terlalu disiplin dengan sistem absensi yang sudah berjalan selama ini.

2. Dalam perekaman data mesin absensi fingerprint cukup memiliki tingkat akurasi yang tinggi dan sebaiknya dalam hal ini institusi dapat memberikan jaminan keamanan rekam sidik jari secara transparan sehingga data kehadiran tidak dapat dimanipulasi.

3. Peningkatan teknologi mesin absensi fingerprint yang lebih baik khususnya dalam hal ketepatan scanner dalam membaca sidik jari. Hal ini dimaksudkan untuk mengatasi masalah deteksi/tidak terbacanya jari yang diletakkan pada sensor mesin fingerprint.

4. Perlakuan adil dengan memberikan reward bagi pegawai yang menaati peraturan dan kebijakan dan memberikan punishment bagi yang melanggar disiplin terutama mengenai jam kerja.

\section{Keterbatasan}

Penelitian ini telah diusahakan dan dilaksanakan sesuai dengna prosedur ilmiah, namun demikian masih memiliki keterbatasan yaitu:

1. Dalam melakukan penyebaran kuesioner, pengisisan oleh responden tidak dapat dilakukan dalam waktu cepat dikarenakan sebagian pegawai melakukan pekerjaan atau aktivitas di luar kantor.

2. Masih terdapat beberapa jawaban kuesioner yang tidak konsisten menurut pengamatan peneliti. Karena responden yang cenderung kurang teliti terhadap pernyataan yang ada.

\section{DAFTAR PUSTAKA}

Afifah, T. (2017). Pengaruh Kepuasan Kerja Terhadap Motivasi Kerja Dan Dampaknya Terhadap Kinerja. Jurnal Administrasi Bisnis, 47.

Harlie, M. (2010). Pengaruh Disiplin Kerja, Motivasi dan Pengembangan Karier Terhadap Kinerja Pegawai Negeri Sipli Pada Pemerintah Kabupaten Tabalog di Tanjung Kalimantan Selatan. Jurnal Manajemen dan Akuntansi.

Hartanto, Hendriana, S., \& Maulida, Y. (2018, April). Analisis Pengaruh Kondisi Kerja, Motivasi Kerja, Dan Disiplin Kerja Terhadap Kinerja Pegawai Kantor Wilayah Direktorat Jenderal Kekayaan Negara Riau, Sumatra Barat, Dan Kepulauan Riau. Jurnal Tepak Manajemen Bisnis, $X$.

Hertyana, H. (2016). Pengaruh Sistem Absensi Fingerprint Terhadap Kinerja Karyawan Pada PT. Deltacomsel Indonesia. Jurnal Teknik Komputer AMIK BSI, II.

Indah Puji Hartatik, S. M. (2014). Buku Praktis Mengembangkan SDM. Jogjakarta: Laksana.

Maeyasari, E. (2012). Pengaruh Efektifitas Penerapan Absensi Fingerprint Terhadap Disiplin Pegawai Negeri Sipil Di Sekretariat Daerah Kabupaten Lebak.

Malayu, H. (2013). Manajemen Sumber Daya Manusia. Jakarta: PT. Bumi Aksara.

Mushlikhun, Hasiolan, L. B., \& Fathoni, A. (2016). Pengaruh Mekanisme Finger Print, Prosedur Finger Print, 
Risfa Fadila \& Maryani S, Pengaruh Penerapan Sistem Absensi...

Pencapaian Target Finger Print Terhadap Kedisiplinan Pegawai di Sekretariat DPR Kota Semarang. Journal of Management.

Nurmalasari, Hartini, S., Adiwihardja, C., \& Muniroh. (2018). Efektivitas Penerapan Absensi Fingerprint Terhadap Disiplin Kerja Karyawan PT. Hillconjaya Sakti Jakarta. Jurnal Seminar Nasional Inovasi dan Tren (SNIT), A-55 - A-60.

Nurraini. (2013). Manajemen Sumber Daya Manusia. Pekanbaru: Yayasan Aini Syam.

Ogbanufe, O., \& Kim, D. J. (2017). Comparing Fingerprint-based Biometrics Authentication versus Traditional Authentication Methods for e-Payment. Decision Support Systems , 106, 1-14.

Octarina, A. (2013). Pengaruh Etos Kerja Dan Disiplin Kerja Terhadap Kinerja Pegawai.

Pangestika, A. A. (2015). Pengembangan Sumber Daya Dengan Statistical Thinking. Official Statistics.

Prihatinta, T. (2017). Hubungan Tingkat Kehadiran Melalui Penerapan Absensi Fingerprint Terhadap Tingkat Disiplin Kerja Karyawan Kontrak Di Politeknik Negeri Madiun. Epicheirisi.

Rantung, R. (2013). Manfaat Dan Pengaruh Penggaruh Absensi Sidik Jari Terhadap Produktivitas Kerja Pegawai Di Universitas Klabat. Journal of Business and Economics.

Santoso. (2016). Perencanaan dan Pembuatan Aplikasi Absensi Dosen Menggunakan Radio Frequency Identification (RFID) . Seminar Nasional Inovasi dan Aplikasi Teknologi di Industri (SENIATI).

Setiawan, D. R., \& Yulianti. (2017, Maret). Pengaruh Absensi Fingerprint Terhadap Disiplin Kerja Karyawan Pada PT. Sanbio Laboratories Gunung Putri Kabupaten Bogor. Jurnal Majalah Ilmiah Institut STIAMI, 14, 70-81.
Sugiyono, P. D. (2018). Metode Penelitian Bisnis (Pendekatan Kuantitatif, Kualitatif dan $R \& D)$. Bandung: Alfabeta.

Sujarweni, V. (2015). Metode Penelitian Bisnis \& Ekonomi. Yogyakarta: Pustakabarupress.

Taboh, P. (2012). Pengaruh Komunikasi dan Disiplin Kerja Terhadap Kinerja Karyawan Pada PT. Sentosa Abadi Semesta PangkalPinang.

Tofik, M. (2010). Panduan Praktis Membuat Aplikasi Penggajian Microsoft Excel 2007. Jakarta: Media Kita.

Ulya. (2017). Pengaruh Keefektifan penggunaan mesin absensi fingerprint dan kondisi lingkungan kerja non fisik terhadap kedisiplinan karyawan. Skripsi eprints walisongo.

Zainul Hidyat, M. (2012). Pengaruh Lingkungan Kerja dan Disiplin Kerja serta Motivasi Kerja Terhadap Kinerja Karyawan Perusahaan Daerah Air Mineral (PDAM). WIGA, 2. 